\title{
Nitrogen Dynamics in Tropical Soils Treated with Liquid and Granular Urea Fertilizers
}

\author{
Ahmmed Md Motasim (D), Abd Wahid Samsuri *(D), Arina Shairah Abdul Sukor and Amin Mohd Adibah
}

check for updates

Citation: Motasim, A.M.; Samsuri, A.W.; Abdul Sukor, A.S.; Adibah, A.M. Nitrogen Dynamics in Tropical Soils Treated with Liquid and Granular Urea Fertilizers. Agriculture 2021, 11, 546. https://doi.org/ 10.3390/agriculture11060546

Academic Editor: Lorenzo Barbanti

Received: 14 April 2021

Accepted: 7 June 2021

Published: 14 June 2021

Publisher's Note: MDPI stays neutral with regard to jurisdictional claims in published maps and institutional affiliations.

Copyright: (c) 2021 by the authors. Licensee MDPI, Basel, Switzerland. This article is an open access article distributed under the terms and conditions of the Creative Commons Attribution (CC BY) license (https:// creativecommons.org/licenses/by/ $4.0 /)$.
Department of Land Management, Faculty of Agriculture, Universiti Putra Malaysia, Serdang 43400, Malaysia; gs53286@student.upm.edu.my (A.M.M.); shairah@upm.edu.my (A.S.A.S.); adibahamin@upm.edu.my (A.M.A.)

* Correspondence: samsuriaw@upm.edu.my

\begin{abstract}
The mineralization of urea fertilizer mostly regulates the nitrogen dynamics in the soil. A laboratory-scale study was conducted to compare the nitrogen dynamics in two tropical soil series incubated with either liquid urea (LU) or granular urea (GU) at 0, 300, 400 or $500 \mathrm{mg} / \mathrm{kg}$ of soil. The soils samples used in the experiment were the Bungor and Selangor soil series which have a sandy clay loam and clay texture, respectively. The $\mathrm{NH}_{4}{ }^{+}-\mathrm{N}, \mathrm{NO}_{3}{ }^{-}-\mathrm{N}$ concentration in the soils were measured for four weeks to determine the urea- $\mathrm{N}$ mineralization while ten pore volumes of water were used for the $\mathrm{NH}_{4}{ }^{+}-\mathrm{N}$ and $\mathrm{NO}_{3}{ }^{-}-\mathrm{N}$ leaching loss. At the same application rate, higher $\mathrm{NH}_{4}{ }^{+}-\mathrm{N}$ and $\mathrm{NO}_{3}{ }^{-}-\mathrm{N}$ concentrations were recorded in the $\mathrm{LU}$ applied soils throughout the incubation period in case of $\mathrm{N}$ mineralization. Urea-N recovery was higher in GU than LU treated soils in the first two weeks while no urea-N was present in both GU and LU treated soils after the third week of incubation. The leaching of $\mathrm{N}\left(\mathrm{NH}_{4}{ }^{+}-\mathrm{N}\right.$ and $\left.\mathrm{NO}_{3}{ }^{-}-\mathrm{N}\right)$ was higher in $\mathrm{GU}$ treated soils than that of LU and leaching was increased with increased application rate in both LU and GU in both soils. The $\mathrm{NH}_{4}{ }^{+}-\mathrm{N}$ and $\mathrm{NO}_{3}{ }^{-}-\mathrm{N}$ concentrations were higher in the Selangor soil whereas the total $\mathrm{N}$ leaching loss was higher in Bungor soil. The results suggest that the LU was a better $\mathrm{N}$ fertilizer source than GU for rapid mineralization, quicker $\mathrm{N}$ availability and lower $\mathrm{N}$ leaching loss.
\end{abstract}

Keywords: $\mathrm{NH}_{4}{ }^{+}-\mathrm{N} ; \mathrm{NO}_{3}{ }^{-}-\mathrm{N}$; liquid urea; $\mathrm{N}$ mineralization; $\mathrm{N}$ leaching

\section{Introduction}

The introduction Nitrogen $(\mathrm{N})$ is an essential element for plants and it is a major constituent of chlorophyll, amino acids, adenosine triphosphate (ATP) and genetic materials and contributes $30-50 \%$ of crop yield increases worldwide [1-3]. Urea is the main $\mathrm{N}$ fertilizer source having significant impact to the global crop production [4]. It is the most widely used $\mathrm{N}$ fertilizer because it is user-friendly and having high $\mathrm{N}$ content (46\%). Urea use covers around $73.4 \%$ of total $\mathrm{N}$ fertilizer utilization globally $[5,6]$. However, the alarming problem associated with the granular urea fertilizer use is its high nitrogen loss and low nitrogen use efficiency (NUE) which ranges from 10-50\% [7]. The highest fraction of urea lost $(64 \%)$ was detected when it was broadcast on the field [8] and without proper fertilizer management, over $50 \%$ of the nitrogen from urea cannot be assimilated by plants. Therefore, it becomes a potential source of environmental degradation such as water pollution, eutrophication, acid rain, ammonia volatilization loss, nitrous oxide emission, global warming and stratospheric ozone depletion [5,9]. Surface application of granular urea promotes significant gaseous loss [10,11] and N leaching loss [9] causing of lower $\mathrm{N}$ availability and ultimately low NUE of applied urea. However, increase of $\mathrm{N}$ availability and control $\mathrm{N}$ losses is inevitable in profitable and sustainable agriculture specially when crop suffers severe $\mathrm{N}$ deficiency and requires urgent $\mathrm{N}$ recovery. In this situation, faster $\mathrm{N}$ mineralization and minimizing $\mathrm{N}$ leaching loss can increase the NUE of applied urea.

Liquid urea (LU) had been recommended to use for the warm periods during a growing season for a quick recovery of $\mathrm{N}$ deficiency [12]. Since then, the use LU fertilizer as 
an alternative $\mathrm{N}$ source to granular urea (GU) is increasingly recommended for profitable cereal production as LU gives better performance in crop yield [13]. Walsh and Christiaens [14] compared LU with other two other liquid $\mathrm{N}$ fertilizers (urea ammonium nitrate and High NRG-N) and they found that LU was the more suitable $\mathrm{N}$ source in terms of $\mathrm{N}$ uptake, NUE and yield. Liquid urea was reported to be more eco-friendly, more efficient uptake and had 19\% higher NUE [15] than the GU. Singh et al. [16] found higher growth, development, N uptake along with $20 \%$ higher wheat yield in LU application than broadcast GU. Application of liquid fertilizer may be more promising in fertilizer use efficiency and lower ecological consequences compared to granular fertilizer [17].

Faulty methods and improper scheduling of urea applications promote losses of nitrogen that lower the NUE of the GU [18]. It is a challenge to increase N availability and restrict leaching of $\mathrm{N}$ from urea application in soil. Judicious management of $\mathrm{N}$ fertilizer along with effective fertilizer placement can attain better mineralization, efficient uptake of nutrient, economic crop production and $\mathrm{N}$ losses minimization. Limited studies have been reported on the comparisons between LU and GU in terms of nitrogen mineralization when the fertilizers were applied to tropical acid soils. The main goal of this study was to evaluate $\mathrm{N}$ mineralization differences of LU and GU applied to two selected soil series, which would allow a better understanding of urea-base $\mathrm{N}$ loss mechanisms in tropical climate soils.

\section{Materials and Methods}

The soils samples used in this study were the Bungor (fine, kaolinitic, isohyperthermic, typic paleudult) and Selangor (very fine, alluvium, isohypertermic, typic endoaquepts) soil series which belong to the order of Ultisols and Inceptisols, respectively, according to the USDA Soil Taxonomy. The Bungor soil was sampled at the field station of the Faculty of Agriculture, Universiti Putra Malaysia $\left(03^{\circ} 00^{\prime} 12.6^{\prime \prime} \mathrm{N}\right.$; $\left.101^{\circ} 47^{\prime} 22.4^{\prime \prime} \mathrm{E}\right)$ while the Selangor soil was sampled from Sungai Besar, Selangor $\left(03^{\circ} 42^{\prime} 20.1^{\prime \prime} \mathrm{N} ; 100^{\circ} 58^{\prime} 08.0^{\prime \prime} \mathrm{E}\right)$. The soils were sampled from the top $15 \mathrm{~cm}$ depth and were air-dried, ground and sieved through a $2.00 \mathrm{~mm}$ sieve. The soils were analysed for total $\mathrm{N}$ using the dry combustion method on a LECO-TruMac, LECO Corporation, St. Joseph, USA [19] CNS analyser, cation exchange capacity (CEC) using the leaching method [20], soil particle distribution using the pipette method [21], the gravimetric water content was determined at field capacity [22] and $\mathrm{pH}$ was determined in 2.5 (soil: water) ratio and measured using Metrohm827 $\mathrm{pH}$ meter, Metrohm AG, Herisau, Switzerland. The properties of both soils are shown in Table 1.

Table 1. Physicochemical properties of the soils.

\begin{tabular}{ccc}
\hline Soil Properties & Bungor Soil & Selangor Soil \\
\hline Texture analysis & $28.44 \%$ clay, $2.28 \%$ silt and & $68.11 \%$ clay, $29.85 \%$ silt and \\
USDA soil texture class & $69.28 \%$ sand & $2.04 \%$ sand \\
Moisture content at field & Sandy clay loam * & Clay \\
capacity $(\%)$ & 23.74 & 27.89 \\
pH & 4.93 & 6.03 \\
Total C $(\%)$ & 1.41 & 3.46 \\
Total N $(\%)$ & 0.07 & 0.27 \\
$\mathrm{NH}_{4}{ }^{-}-\mathrm{N}(\mathrm{mg} / \mathrm{kg})$ & 16.31 & 10.07 \\
$\mathrm{NO}_{3}{ }^{-}-\mathrm{N}(\mathrm{mg} / \mathrm{kg})$ & 11.41 & 27.11 \\
$\mathrm{CEC}(\mathrm{cmol}+/ \mathrm{kg})$ & 5.78 & 16.48 \\
\hline${ }^{*}[23]$. & &
\end{tabular}

The incubation study was conducted in laboratory at a room temperature lit with fluorescent light to determine $\mathrm{N}$ mineralization during four weeks of incubation. The LU and GU fertilizers were applied to the surface of the two soils placed in $100 \mathrm{~cm}^{3}$ plastic pots at either $0,300,400$ or $500 \mathrm{mg} / \mathrm{kg}$ soil. Freshly prepared $1.20 \%(w / v), 1.60 \%(w / v)$ and $2.00 \%$ $(w / v)$ of urea solution @ $2.5 \mathrm{~mL} / 100 \mathrm{~g}$ soil were applied at either 300,400 or $500 \mathrm{mg} / \mathrm{kg}$ soil, 
respectively, in $50 \mathrm{~g}$ of sieved air-dried soil and kept open to maintain the aerobic condition. The moisture content was maintained at field capacity during the incubation period by adding water to maintain the initial weight. The $\mathrm{N}$ mineralization was analyzed weekly following destructive technique [24]. In this method, $20 \mathrm{~g}$ soil was extracted with $40 \mathrm{~mL}$ of potassium chloride-phenyl mercuric acetate (KCl-PMA) solution that was distilled with micro-Kjeldhal steam distillation unit and titrated against $0.01 \mathrm{~N} \mathrm{HCl}$ solution. The urea-N was estimated by extracting $20 \mathrm{~g}$ soil with $40 \mathrm{~mL}$ of KCl-PMA solution. The solution was reacted with coloring reagents (Di-acetyl monoxime and Thio-semi-carbazide) and the color intensity was measured with calibrated spectrophotometer (CECIL, CE1011, CECIL Instruments Limited, Cambridge, England, UK) at $528 \mathrm{~nm}$ wavelength [25]. The amount of $\mathrm{N}(\%)$ remaining in the soil at the end of the incubation was measure using LECO-Trumac CNS analyser as mentioned above.

The leaching study was done by using leachate tubes $(10 \mathrm{~cm}$ diameter and $60 \mathrm{~cm}$ height) with $100 \mathrm{~g}$ of sieved air-dried soil. The soil columns were wetted over night by adding distilled water and the moisture content was maintained at field capacity. After two days of treatment application, $100 \mathrm{~mL}$ of distilled water was added and the leached solution was collected up to 10 pore volumes [26]. The leached solutions were analyzed for $\mathrm{NH}_{4}{ }^{+}-\mathrm{N}$ and $\mathrm{NO}_{3}{ }^{-}-\mathrm{N}$ concentration [24]. The temperature of the incubation room was maintained at $25 \pm 0.5^{\circ} \mathrm{C}$ throughout the study. The experiment was conducted as a complete factorial design and the experimental units were arranged in a completely randomized design with four replicates.

\section{Statistical Analysis}

The data were statistically analyzed as a complete factorial experimental design with Statistical Analysis Software (SAS) 9.4 (SAS Institute Inc., Cary, NC, USA (2013) [27] and differences between treatment means were compared using the least significant difference (LSD) test at the $5 \%$ level of significance.

\section{Results}

\section{1. $\mathrm{NH}_{4}{ }^{+}-\mathrm{N}$ and $\mathrm{NO}_{3}{ }^{-}-\mathrm{N}$ Concentrations}

At the same application rate, higher $\mathrm{NH}_{4}{ }^{+}-\mathrm{N}$ and $\mathrm{NO}_{3}{ }^{-}-\mathrm{N}$ concentrations were recorded in $\mathrm{LU}$ treated soils compared to the $\mathrm{GU}$ in both soils. The $\mathrm{NH}_{4}{ }^{+}-\mathrm{N}$ concentrations decreased while $\mathrm{NO}_{3}{ }^{-}-\mathrm{N}$ concentrations increased with increasing incubation time and both concentrations increased with increasing application rates. Among the two soils, $\mathrm{NH}_{4}{ }^{+}-\mathrm{N}$ and $\mathrm{NO}_{3}{ }^{-}-\mathrm{N}$ concentrations were higher in Selangor soil than Bungor soil when compared at the same rate of $\mathrm{LU}$ and $\mathrm{GU}$ applications. The $\mathrm{NH}_{4}{ }^{+}-\mathrm{N}$ concentrations were high in the first week and then decreased gradually to the fourth week in Bungor and Selangor soils. Similar patterns were recorded from both LU and GU treated soils. On the other hand, the $\mathrm{NO}_{3}{ }^{-}-\mathrm{N}$ concentrations were low in the first week and then it increased gradually throughout the whole incubation time in Selangor soil. However, in Bungor soil, the $\mathrm{NO}_{3}{ }^{-}-\mathrm{N}$ concentrations were low in the first week and then gradually increased and peaked at the third week before it became lower at the fourth week of the incubation. Similar results were observed in both LU and GU treated soils.

In Bungor soil series, the amount of $\mathrm{NH}_{4}{ }^{+}-\mathrm{N}$ concentration and rate of urea mineralization (\%) in the soils were higher in the first week of incubation and then gradually decreased until the fourth week of incubation, both for LU and GU treatments (Figure 1A). In GU400 treated soils, $13.31 \%, 8.67 \%, 5.79 \%$ and $5.05 \%$ of urea mineralized to $\mathrm{NH}_{4}{ }^{+}-\mathrm{N}$ in the 1st, 2nd, 3rd and 4th week of incubation, respectively, which were the highest among the GU treatments in respective weeks. The mineralization rates increased with increased GU application rates. In LU400 treated soils, $18.35 \%, 8.91 \%, 5.92 \%$ and $3.46 \%$ of urea were mineralized to $\mathrm{NH}_{4}{ }^{+}-\mathrm{N}$ in the 1st, 2nd, 3rd and 4th week of incubation, respectively, and similar to the GU, the mineralization rates increased with increased LU application rates. In the first two weeks of incubation, the mineralization rates were higher in LU than GU but in the last two weeks, the mineralization rates were higher in GU than LU treated soils. The 
lowest concentration and rate of urea mineralization (\%) to $\mathrm{NO}_{3}{ }^{-}-\mathrm{N}$ in the Bungor soils were measured in the first week and the values increased gradually until the third week of incubation and then the values decreased at the fourth week of incubation (Figure 2A). The same patterns were observed in both $\mathrm{GU}$ and $\mathrm{LU}$ treated soils. The highest rate of $\mathrm{NO}_{3}{ }^{-} \mathrm{N}$ mineralization (\%) in the GU treated soils was highest in the GU300 when compared at the same week of incubation. Similarly, the highest rate (\%) of $\mathrm{NO}_{3}{ }^{-}-\mathrm{N}$ mineralization in the $\mathrm{LU}$ treated soils was found in the $\mathrm{LU} 300$ treated soils. The rate of $\mathrm{NO}_{3}{ }^{-}-\mathrm{N}$ mineralization (\%) was higher in the LU than GU treated soils when compared at the same incubation week and application dosage (Figure 2).

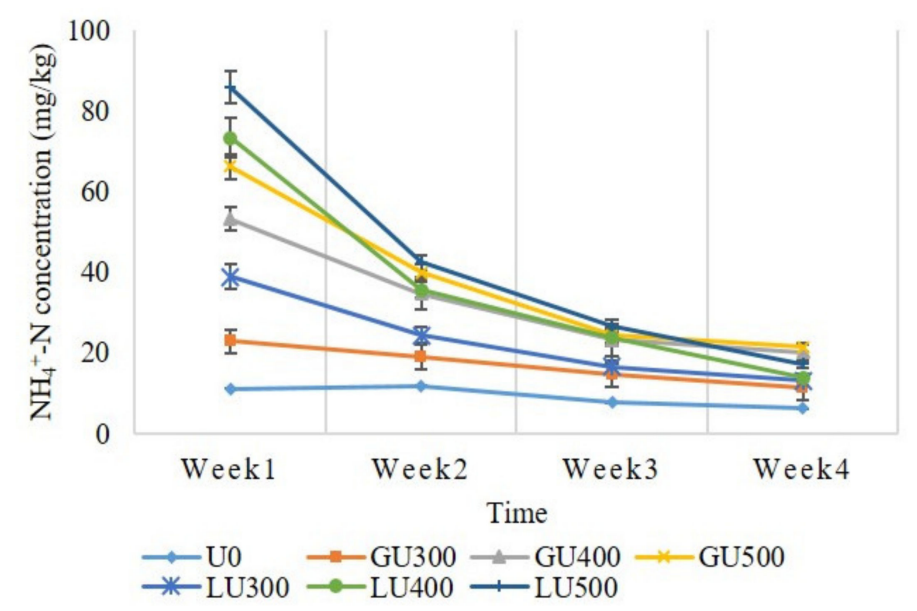

(A)

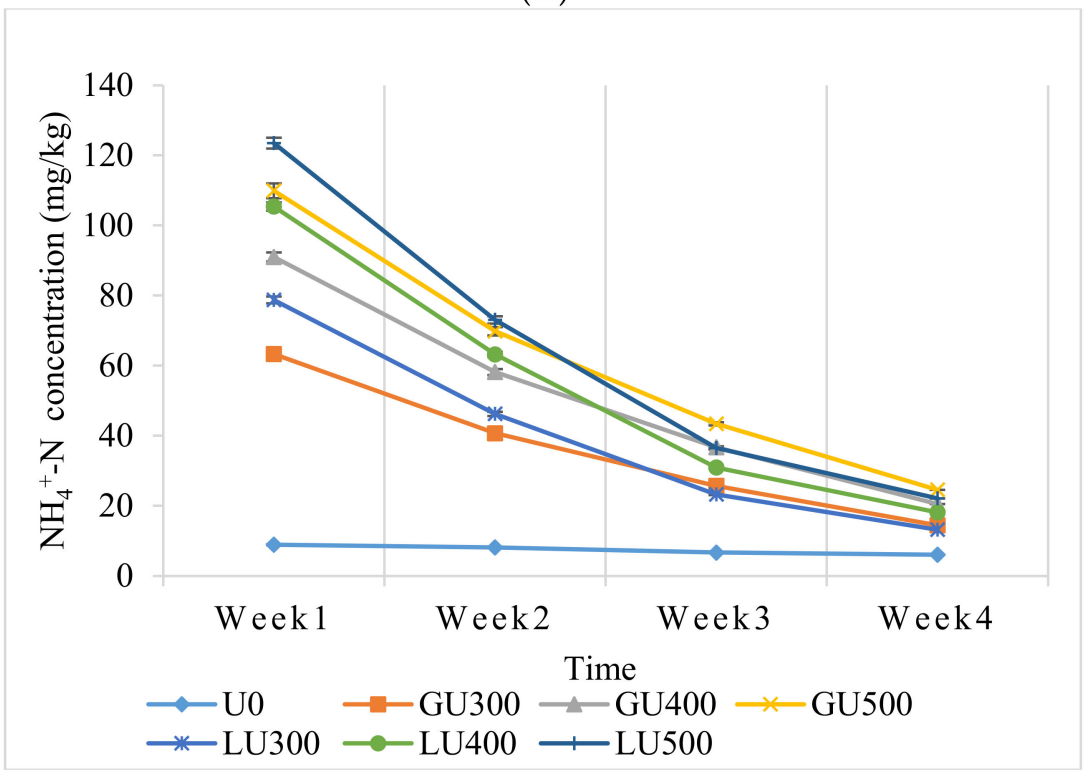

(B)

Figure 1. $\mathrm{NH}_{4}{ }^{+}-\mathrm{N}$ concentration (mg/kg) in Bungor (A) and Selangor (B) soils treated with different rate of LU and GU fertilizers during the four weeks of incubation. Vertical bars on the graphs show the standard errors. 


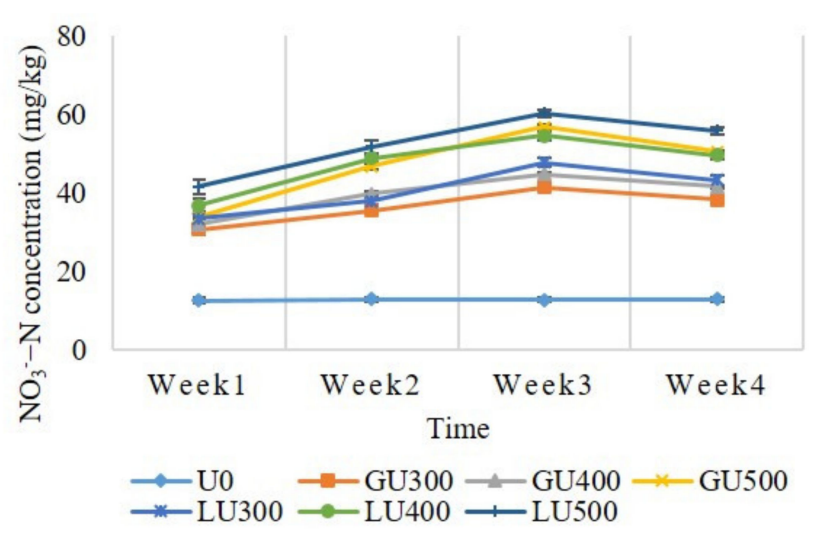

(A)

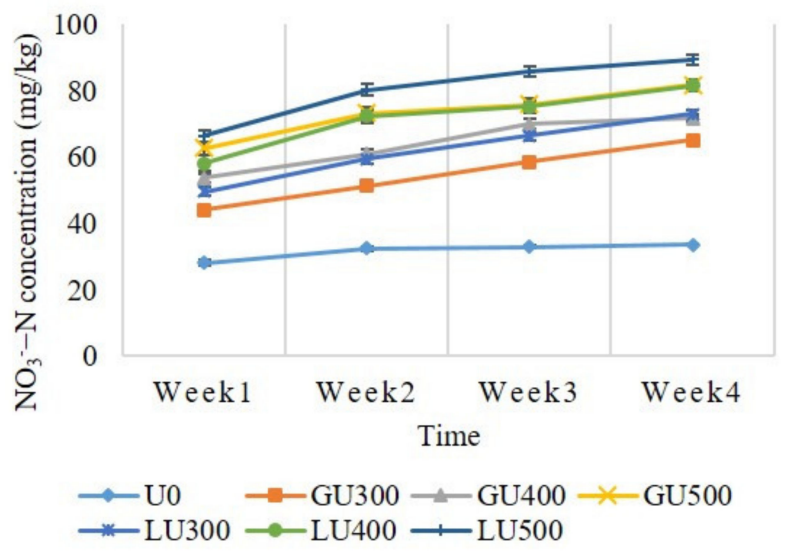

(B)

Figure 2. $\mathrm{NO}_{3}{ }^{-}-\mathrm{N}$ concentration in Bungor (A) and Selangor $(\mathbf{B})$ soils treated with different rate of LU and GU fertilizers during the four weeks of incubation. Vertical bars on the graphs show the standard errors.

In Selangor soil, the amount of $\mathrm{NH}_{4}{ }^{+}-\mathrm{N}$ concentrations were highest in the first week of incubation for both LU and GU treated soils, and the values decreased gradually until the fourth week of incubation (Figure 1B). In GU400 treated soils, 22.75\%, 15.54\%, 9.17\% and $5.13 \%$ of urea mineralized to $\mathrm{NH}_{4}{ }^{+}-\mathrm{N}$ in $1 \mathrm{st}, 2 \mathrm{nd}$, 3rd and 4 th week of incubation, respectively, which were the highest among the GU treatments in respective weeks. The mineralization rates increased with GU application rate. Similarly, the LU400 treated soils mineralized $26.35 \%, 15.80 \%, 7.73 \%$ and $24.54 \%$ of urea to $\mathrm{NH}_{4}{ }^{+}-\mathrm{N}$ in the 1 st, 2 nd, 3rd and 4th week of incubation, respectively, which were the highest among the LU treatments in respective weeks and the rate of urea mineralization to $\mathrm{NH}_{4}{ }^{+}-\mathrm{N}$ increased with the increased LU application rate similar to what was observed on the GU treated soils. However, the concentration and rate (\%) of urea conversion to $\mathrm{NO}_{3}{ }^{-}-\mathrm{N}$ in Selangor soil were lowest in the first week of incubation and then increased gradually until the fourth week of incubation (Figure 2B). The highest rate of urea conversion to $\mathrm{NO}_{3}{ }^{-}-\mathrm{N}$ among the GU and LU treated soils were recorded in the GU300 and LU300 soils, respectively. When compared at the same application rate and incubation week, the rate of urea conversion to $\mathrm{NO}_{3}{ }^{-}-\mathrm{N}$ in the $\mathrm{LU}$ treated soils were higher than the GU treated soils.

\subsection{Urea-N Remaining (\%) in the Soil}

The amount of urea-N remaining in both soils decreased with time with higher amount of remaining urea-N recorded in the GU than the LU treated soils when compared at the same application rate. The urea- $\mathrm{N}$ concentrations in both soils were higher in soils receiving higher rates of urea application. The amounts of urea-N remaining in both soils were high in the first week of incubation and gradually decreased up to the second week after which no more urea- $\mathrm{N}$ was detected. The higher amount of urea-N was remained in $\mathrm{GU}$ than LU treated soils meaning that $\mathrm{NH}_{4}{ }^{+}-\mathrm{N}$ and of $\mathrm{NO}_{3}{ }^{-}-\mathrm{N}$ conversion was the slowest in GU treated soils. The urea-N remained was highest in the first week for all the treated soils whose were continued to the second week and no urea-N was present in GU and LU treated soils after the third week of incubation in both soils. In Bungor soil, the amounts of urea- $\mathrm{N}$ remaining in the soil were the highest in the first week, and then decreased gradually from the second week of incubation in LU and GU treated soils (Figure 3A). 


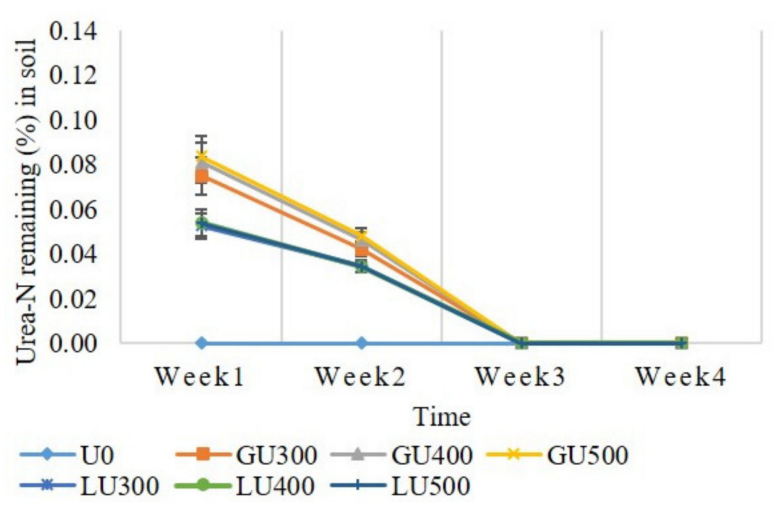

(A)

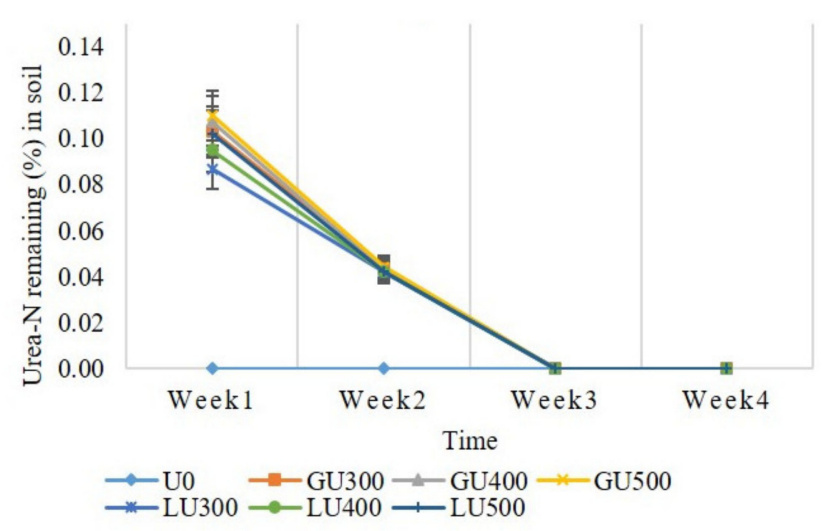

(B)

Figure 3. Urea-N remaining (\%) in Bungor (A) and Selangor (B) soils treated with different rate of LU and GU fertilizers during the four weeks of incubation. Vertical bars on the graphs show the standard errors.

However, the percentages of urea-N remaining in the soils treated with higher GU rates were higher than those with lower application rates in the first and second week of incubation and after third week of incubation, no urea-N was detected in any of the treated soils. In LU treated soils, the percentages of urea-N remaining were higher in the first week and lower in the second week but equal in application rates at each week and after third week of incubation, no urea-N was detected like GU treated soils. In Selangor soil series, the amounts of urea-N remaining in the soil were the highest in the first week, and then decreased gradually from the second week of incubation in LU and GU treated soils (Figure 3B). The percentages of urea-N remaining in the soils treated with higher GU rates were higher than those with lower application rates in the first and second week of incubation and after that, no urea-N was detected in any of the treated soils. The percentages of urea-N remaining in the soils treated with higher LU rates were higher than those with lower application rates in the first week but equal in application rates in the second week of incubation and after third week of incubation, no urea- $\mathrm{N}$ was detected like GU treated soils. The amount of urea-N remaining in Selangor soils were significantly $(p<0.05)$ higher than that of Bungor during the first and second week of incubation when compared at the same application rate for both GU and LU treatments.

\subsection{Leaching Loss of $\mathrm{N}\left(\mathrm{NH}_{4}{ }^{+}-\mathrm{N}\right.$ and $\left.\mathrm{NO}_{3}{ }^{-}-\mathrm{N}\right)$ from Applied Urea}

The leaching loss $\mathrm{NH}_{4}{ }^{+}-\mathrm{N}$ and $\mathrm{NO}_{3}{ }^{-}-\mathrm{N}$ was recorded higher in $\mathrm{GU}$ than that of $\mathrm{LU}$ treated soils in both Bungor and Selangor soil series and the leaching loss was increased with increased application rate of urea (Figures 4 and 5). In the 2nd and 3rd pores, the leaching loss was higher and later drastically lower in both soil series.

In Bungor soil series, $\mathrm{NH}_{4}{ }^{+}-\mathrm{N}$ leaching was low in first two pores which not significant among the treatments $(p>0.05)$. After 2 nd pore, it jumped extremely and after that gradually low. In 6th pore and onward, it was lower. In 3rd-5th pore, significantly higher amount of $\mathrm{NH}_{4}{ }^{+}-\mathrm{N}$ was lost by leaching from GU treated soils than that of $\mathrm{LU}$ in corresponding rate of applications (Figure $5 \mathrm{~A}$ ). The highest cumulative $\mathrm{NH}_{4}{ }^{+}-\mathrm{N}$ concentration was recorded $71.71(\mathrm{mg} / \mathrm{kg})$ in leachate from GU500 treated soil and this value was $64.58(\mathrm{mg} / \mathrm{kg}$ ) from LU500 treated soil (Table 2). In Selangor soil series, after the 1st pore, $\mathrm{NH}_{4}{ }^{+}-\mathrm{N}$ leaching was drastically high until 3rd pore before it became drastically low at 4 th pore onwards. The higher $\mathrm{NH}_{4}{ }^{+}-\mathrm{N}$ leaching loss was recorded in $\mathrm{GU}$ treatment than that of LU in corresponding application rates in first 5 pore volumes and later irregular and had no significant differences (Figure 5B). The cumulative $\mathrm{NH}_{4}{ }^{+}-\mathrm{N}$ leaching was higher in GU treated soils than that of LU and increased with the increased rate of urea application. The highest cumulative $\mathrm{NH}_{4}{ }^{+}-\mathrm{N}$ concentration was recorded $30.63(\mathrm{mg} / \mathrm{kg})$ in leachate from GU500 treated soil and it was $26.98(\mathrm{mg} / \mathrm{kg}$ ) from LU500 treated soil (Table 2). 


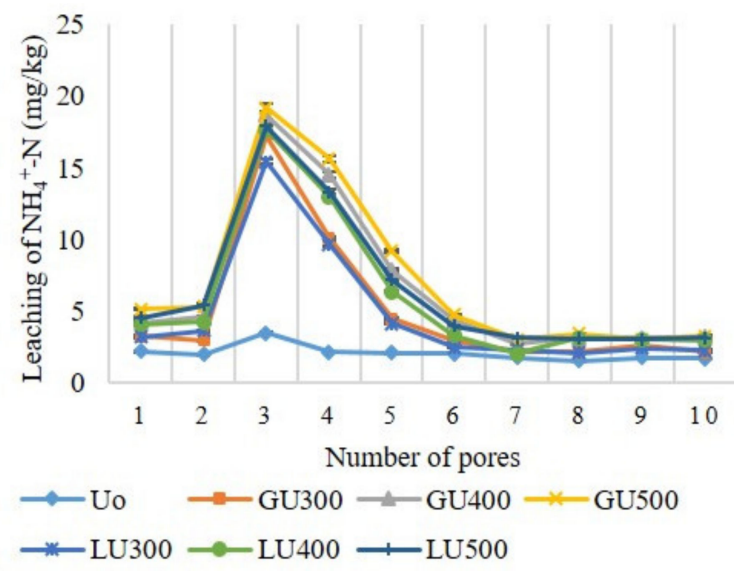

(A)

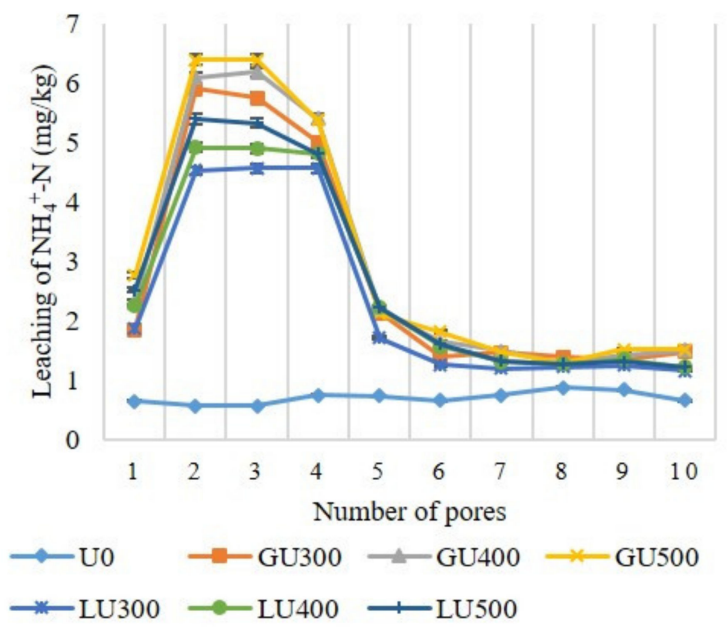

(B)

Figure 4. Leaching of $\mathrm{NH}_{4}{ }^{+}-\mathrm{N}(\mathrm{mg} / \mathrm{kg})$ from Bungor (A) and Selangor (B) soils treated with different rate of LU and GU fertilizers in 10 pore volumes. Vertical bars on the graphs show the standard errors.

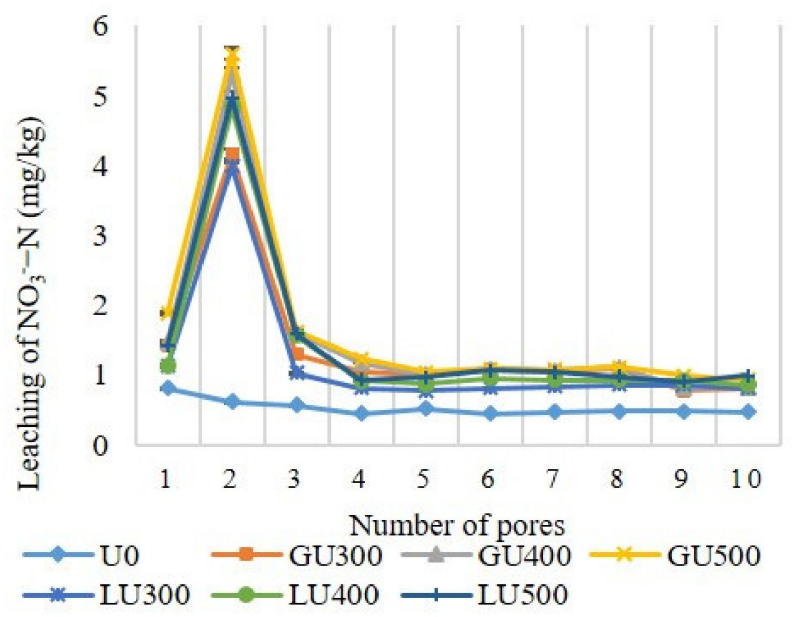

(A)

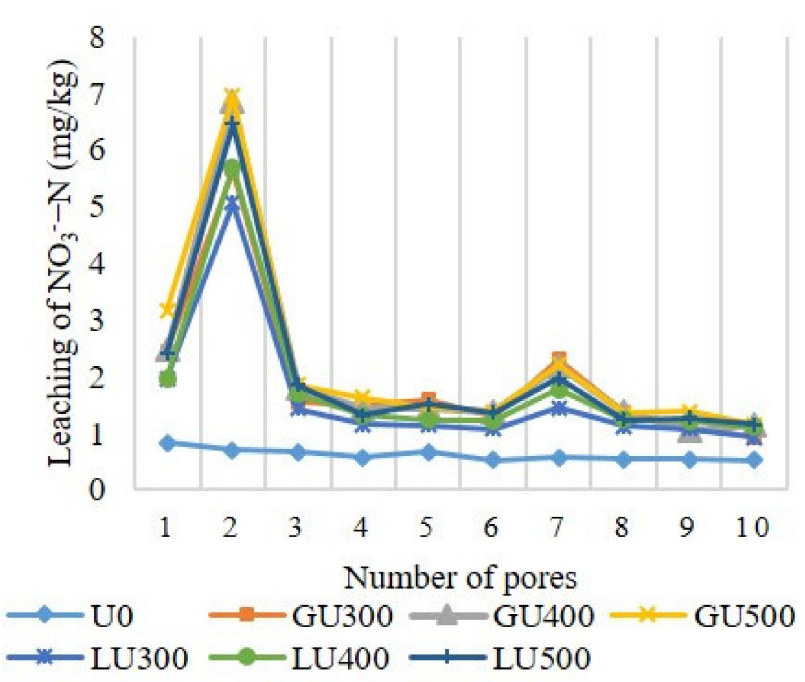

(B)

Figure 5. Leaching of $\mathrm{NO}_{3}{ }^{-}-\mathrm{N}(\mathrm{mg} / \mathrm{kg})$ from Bungor (A) and Selangor (B) soils treated with different rate of LU and GU fertilizers in 10 pore volumes. Vertical bars on the graphs show the standard errors.

The leaching loss of $\mathrm{NO}_{3}{ }^{-}-\mathrm{N}$ was recorded higher in 2nd pore volume and later drastically low. In first three pore volumes, the significantly higher $\mathrm{NO}_{3}{ }^{-}-\mathrm{N}$ was lost from GU treated soils than that of LU with corresponding rate of urea application and later insignificant and uneven. The cumulative loss of $\mathrm{NO}_{3}{ }^{-}-\mathrm{N}$ was found higher in GU treated soils than that of LU and increased with the increased rate of application (Figure 5A). The highest cumulative $\mathrm{NO}_{3}{ }^{-}-\mathrm{N}$ concentration was recorded $16.55(\mathrm{mg} / \mathrm{kg})$ in leachate from GU500 treated soil and it was $14.82(\mathrm{mg} / \mathrm{kg}$ ) recorded from LU500 treated soil (Table 2).

The leaching loss of $\mathrm{NO}_{3}{ }^{-}-\mathrm{N}$ was recorded higher in 2nd pore volume and later drastically low. In first two pore volumes, the significantly higher $\mathrm{NO}_{3}{ }^{-}-\mathrm{N}$ was lost from GU treated soils than that of LU with corresponding rate of urea application and later insignificant and irregular. In 7th volume, $\mathrm{NO}_{3}{ }^{-}-\mathrm{N}$ leaching lost was quite higher in GU treated soils, but it was statistically not significant. The cumulative loss of $\mathrm{NO}_{3}{ }^{-}-\mathrm{N}$ was 
found higher in GU treated soils than that of LU and leaching loss increased with increased rate of urea applications (Figure 5B). The highest cumulative $\mathrm{NO}_{3}{ }^{-}-\mathrm{N}$ concentration was recorded $22.76(\mathrm{mg} / \mathrm{kg})$ in leachate from GU500 treated soil and it was $20.74(\mathrm{mg} / \mathrm{kg})$ from LU500 treated soil (Table 2). The cumulative leaching loss of $\mathrm{NH}_{4}{ }^{+}-\mathrm{N}$ was higher in Bungor soil series whereas leaching loss of $\mathrm{NO}_{3}{ }^{-}-\mathrm{N}$ was higher in Selangor soil series. The higher rate of urea application got into more leaching loss trouble than lower application rate.

Table 2. Cumulative leaching loss of $\mathrm{N}\left(\mathrm{NH}_{4}{ }^{+}-\mathrm{N}\right.$ and $\left.\mathrm{NO}_{3}{ }^{-}-\mathrm{N}\right)$ from applied urea.

\begin{tabular}{|c|c|c|c|c|}
\hline \multirow{2}{*}{$\begin{array}{c}\text { Urea } \\
\text { Application } \\
\text { (mg/kg) }\end{array}$} & \multicolumn{2}{|c|}{ Bungor Soil Series } & \multicolumn{2}{|c|}{ Selangor Soil Series } \\
\hline & $\begin{array}{c}\mathrm{NH}_{4}{ }^{+}-\mathrm{N} \\
(\mathrm{mg} / \mathrm{kg})\end{array}$ & $\begin{array}{c}\mathrm{NO}_{3}{ }^{-}-\mathrm{N} \\
(\mathrm{mg} / \mathrm{kg})\end{array}$ & $\begin{array}{c}\mathrm{NH}_{4}^{+}-\mathrm{N} \\
(\mathrm{mg} / \mathrm{kg})\end{array}$ & $\begin{array}{c}\mathrm{NO}_{3}{ }^{-}-\mathrm{N} \\
(\mathrm{mg} / \mathrm{kg})\end{array}$ \\
\hline U0 & $20.46^{*} \pm 0.29 \mathrm{f}$ & $5.25 \pm 0.03 \mathrm{f}$ & $7.04 \pm 0.10 \mathrm{f}$ & $6.15 \pm 0.06 \mathrm{~g}$ \\
\hline GU300 & $49.93 \pm 0.69 \mathrm{~d}$ & $13.68 \pm 0.11 \mathrm{~d}$ & $27.69 \pm 0.39 c$ & $19.91 \pm 0.21 \mathrm{~d}$ \\
\hline GU400 & $66.34 \pm 0.93 b$ & $15.43 \pm 0.14 b$ & $29.47 \pm 0.43 b$ & $21.32 \pm 0.22 b$ \\
\hline GU500 & $71.71 \pm 1.20 \mathrm{a}$ & $16.55 \pm 0.14 \mathrm{a}$ & $30.63 \pm 0.44 \mathrm{a}$ & $22.76 \pm 0.24 \mathrm{a}$ \\
\hline LU300 & $47.51 \pm 0.66 \mathrm{e}$ & $11.88 \pm 0.11 \mathrm{e}$ & $23.29 \pm 0.35 \mathrm{e}$ & $16.56 \pm 0.18 f$ \\
\hline LU400 & $59.79 \pm 0.83 c$ & $13.91 \pm 0.12 \mathrm{~d}$ & $25.80 \pm 0.37 \mathrm{~d}$ & $18.63 \pm 0.19 \mathrm{e}$ \\
\hline LU500 & $64.58 \pm 0.93 b$ & $14.82 \pm 0.12 c$ & $26.98 \pm 0.38 c$ & $20.74 \pm 0.22 c$ \\
\hline $\mathrm{LSD}_{0.05}$ & 2.3262 & 0.323 & 1.0792 & 0.5748 \\
\hline
\end{tabular}

* Different letters within a column indicate significant difference between means using least significant difference (LSD) test at the 0.05 significant level.

\subsection{Total Remaining N (\%) in the Soils}

The total remaining $\mathrm{N}(\%)$ in the soils are presented in the Figure 6 after thirtieth day of incubation.

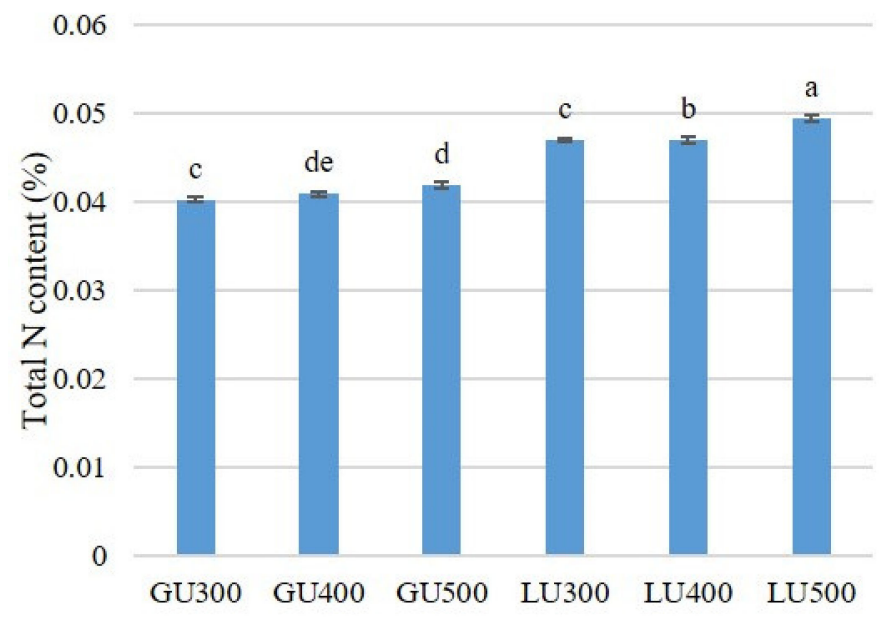

(A)

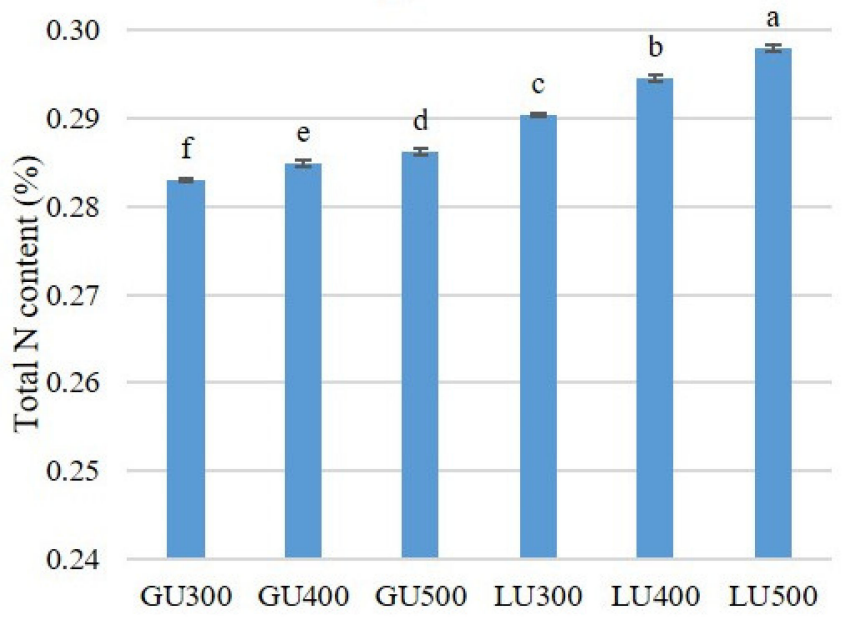

(B)

Figure 6. Total remaining N (\%) in Bungor (A) and Selangor (B) soils applied with different rates of LU and GU fertilizers at the end of 30 days of incubation. Different letters indicate significant difference between means using least significant difference (LSD) test at the 5\% significant level. Vertical bars on the graphs show the standard errors.

The remaining total $\mathrm{N}$ in the soil was higher in LU treated soils than GU while compared at the equal rate of application. The remaining $\mathrm{N}$ in soil was proportional to the application rate of urea. In Bungor soil series, the highest remaining $\mathrm{N}$ was found in soil applied with $500 \mathrm{mg} / \mathrm{kg}$ urea whereas the lowest value was in the soil applied with $300 \mathrm{mg} / \mathrm{kg}$ urea in both LU and GU applications (Figure 6A). The remaining N in soil increased with the increased application rate of both LU and GU in the soil. In Selangor soil series, the highest remaining $\mathrm{N}$ was found in soil applied with $500 \mathrm{mg} / \mathrm{kg}$ urea whereas the lowest value was in the soil applied with $300 \mathrm{mg} / \mathrm{kg}$ urea in both LU and GU applications 
(Figure 6B) alike to Bungor soil series. The total remaining $\mathrm{N}$ in LU treated soils were higher than GU application as same as Bungor soil series. However, the total remaining $\mathrm{N}$ in Selangor soil series was much higher than that of Bungor at the end of incubation in case of both LU and GU applications.

The $\mathrm{NH}_{4}{ }^{+}-\mathrm{N}$ and $\mathrm{NO}_{3}{ }^{-}-\mathrm{N}$ concentrations were higher in $\mathrm{LU}$ treated soils than that of GU (Figures 1 and 2) whereas remaining urea-N (Figure 3) and $\mathrm{NH}_{4}{ }^{+}-\mathrm{N}$ and $\mathrm{NO}_{3}{ }^{-} \mathrm{N}$ leaching (Figures 4 and 5) was higher in the GU treated soils than that of LU applications. Therefore, the total remaining $\mathrm{N}$ in the soils at the end of the incubation period was higher in the LU applications (Figure 6). In addition, the total remaining $\mathrm{N}$ in the Selangor soil was much higher than Bungor soil treated with both LU and GU application at the end of incubation.

\section{Discussion}

When urea is applied to soils, it undergoes the hydrolysis process by adsorbing water to produce $\mathrm{NH}_{4}{ }^{+}$and $\mathrm{HCO}_{3}{ }^{-}$[28]. The whole process is catalyzed by the urease enzyme. Soil moisture was reported to be a significant factor for starting the hydrolysis process of urea [29]. The $\mathrm{NH}_{4}$ can be either adsorbed by soil colloids or can be further transformed to $\mathrm{NO}_{3}$ and $\mathrm{NH}_{3}$ depending on soil conditions. In the $\mathrm{LU}$, the urea has been hydrolyzed even prior to soil application whereas the urea in GU must be hydrolyzed after application before it can be transformed to $\mathrm{NH}_{4}$. Rapid hydrolysis happens in few days and about $80 \%$ of applied urea can be hydrolyzed within the first 4 days after application [30,31]. Urea mineralization in LU was the faster than GU -applied soil. The urea in the LU applied soil is uniformly distributed throughout the soil because it is in a liquid form. Therefore, more $\mathrm{NH}_{4}{ }^{+}$are adsorbed by the soil colloids and this can inhibit further transformation of $\mathrm{NH}_{4}{ }^{+}$ to ammonia gas [32]. In a previous study we observed lower the $\mathrm{NH}_{3}$ volatilization loss in LU treated soil than GU treated soil [11]. This can be the reason why higher concentration of $\mathrm{NH}_{4}{ }^{+}-\mathrm{N}$ and $\mathrm{NO}_{3}{ }^{-}-\mathrm{N}$ was measured in the $\mathrm{LU}$ than $\mathrm{GU}$ treated soil in this study. Surface application of urea as in the GU applied soil promotes higher $\mathrm{NH}_{4}{ }^{+}-\mathrm{N}$ transformation to higher $\mathrm{NH}_{3}$ volatilization loss [33]. The urea mineralization process influenced the amount of urea-N remaining in the soils. The urea- $\mathrm{N}$ remaining from the applied urea in the soil is lower if the $\mathrm{NH}_{4}-\mathrm{N}$ mineralization is higher and and the nitrification process is faster [34]. The LU had a faster $\mathrm{N}$ mineralization and more $\mathrm{NH}_{4}{ }^{+}$mineralized compared to the GU and therefore the $\mathrm{LU}$ had lower urea- $\mathrm{N}$ remaining in the soils.

The concentration of $\mathrm{NH}_{4}{ }^{+}-\mathrm{N}$ and $\mathrm{NO}_{3}{ }^{-}-\mathrm{N}$ were higher in Selangor than Bungor soil for both GU and LU treatments. The clayey Selangor soil series (Inceptisols) may had adsorbed more $\mathrm{NH}_{4}{ }^{+}-\mathrm{N}$ than the sandier Bungor soil series (Ultisols) because it had higher CEC $\left(16.48 \mathrm{cmol}_{+} / \mathrm{kg}\right)$ than the Bungor $\left(5.78 \mathrm{cmol}_{+} / \mathrm{kg}\right)$ soils. Soil colloids such as clay particles can be negatively or positively charged and, therefore, they can adsorb both cations and anions. As such, clay particles contribute to the cation and anion exchange capacity of soils [35].

The results of our study revealed that significantly $(p \leq 0.05)$ higher $\mathrm{NH}_{4}{ }^{+}-\mathrm{N}$ leaching loss was detected from GU than LU treated soils. The first few pore volumes had the higher $\mathrm{NH}_{4}{ }^{+}-\mathrm{N}$ because the urea hydrolysis was high in the first few days of its application before it become low [30]. The rapid hydrolysis of urea promotes higher $\mathrm{N}$ leaching $[36,37]$. The urea in the GU applied soil was more localized compared to the LU soil which was more uniformly distributed throughout the soil. In other words, the urea was more concentrated but over a smaller amount of soil and therefore the leaching loss was more in the GU applied soil [38]. The $\mathrm{NH}_{4}{ }^{+}-\mathrm{N}$ leaching was higher in Bungor soil series than that Selangor soil (Table 2) because the Selangor soil had higher CEC which can enable the soil to adsorb more $\mathrm{NH}_{4}{ }^{+}-\mathrm{N}$. The clayey Selangor also had higher water holding capacity that can hold more $\mathrm{NH}_{4}{ }^{+}$ions and reduced leaching of $\mathrm{NH}_{4}{ }^{+}-\mathrm{N}$ [38]. In the Selangor soils, the abundance of $\mathrm{NH}_{4}{ }^{+}-\mathrm{N}$ can be transformed to $\mathrm{NO}_{3}{ }^{-}-\mathrm{N}$ by the nitrification process [36]. Gioacchini et al. [37] also reported higher $\mathrm{N}$ leaching in light textured (sandy loam) soil than relatively heavy textured (clay loam) soil. 
The $\mathrm{NO}_{3}{ }^{-}-\mathrm{N}$ leaching was recorded higher in $\mathrm{GU}$ treated soils than in of $\mathrm{LU}$ treated soils and the $\mathrm{NO}_{3}{ }^{-}-\mathrm{N}$ leaching also increased with increasing rate of urea applications. The highest leaching of $\mathrm{NO}_{3}{ }^{-}-\mathrm{N}$ was found in the 2 nd pore volume of the incubation study. The concentration of urea in the $\mathrm{GU}$ applied soil was more localized and this encouraged higher $\mathrm{NO}_{3}{ }^{-}$-N leaching [39] compared to the LU applied soil where the urea was more uniformly distributed throughout the soil. The LU was distributed evenly throughout the soil column quickly resulting in lower $\mathrm{NO}_{3}{ }^{-}-\mathrm{N}$ leaching. Tripolskaja et al. [40] found higher leaching loss of $\mathrm{NO}_{3}{ }^{-}-\mathrm{N}$ from simple granular NPK fertilizer than liquid $\mathrm{N}$ fertilizers (Liquid fertilizer Lyderis 9-9-9 and Liquid fertilizer UAN 32). Both the concentration and the leaching of $\mathrm{NO}_{3}{ }^{-}-\mathrm{N}$ was higher in the Selangor soils than the Bungor soils. The Selangor soils which have higher CEC $\left(16.48 \mathrm{cmol}_{+} / \mathrm{kg}\right)$ would repel more negatively charged anionic $\mathrm{NO}_{3}{ }^{-}$than Bungor soil which had lower $\mathrm{CEC}\left(5.78 \mathrm{cmol}_{+} / \mathrm{kg}\right)$ and the same results have been reported by other researchers who compared the $\mathrm{NO}_{3}{ }^{-}$-N.leaching from soil of different CEC values [36,41]. The total $\mathrm{N}\left(\mathrm{NH}_{4}{ }^{+}-\mathrm{N}\right.$ and $\left.\mathrm{NO}_{3}{ }^{-}-\mathrm{N}\right)$ loss through leaching was higher in Bungor soil series than in Selangor soil series (Table 2). Ulen and Aronsson [42] also recorded higher $\mathrm{N}$ leaching loss in light textured soil than fine textured soil.

The total N remaining was higher in the clayey Selangor soil series than sandy Bungor soils applied with both LU and GU at the end of incubation, possibly because of the greater CEC of Selangor soils that can absorb more $\mathrm{NH}_{4}{ }^{+}-\mathrm{N}$. According to the results of this study, the $\mathrm{LU}$ had higher concentrations of $\mathrm{NH}_{4}{ }^{+}-\mathrm{N}$ and $\mathrm{NO}_{3}{ }^{-}-\mathrm{N}$ as well as lower leaching loss because higher $\mathrm{N}$ mineralization in the LU applied soils and higher adsorption of $\mathrm{NH}_{4}{ }^{+}-\mathrm{N}$ by the soil particles.

\section{Conclusions}

The LU application resulted in in higher soil $\mathrm{NH}_{4}{ }^{+}-\mathrm{N}_{\text {and }} \mathrm{NO}_{3}{ }^{-}-\mathrm{N}$ concentrations and lower leaching loss from both soils compared to the GU fertilization. In addition, the LU performed better in the clayey Selangor soil than the sandy clay Bungor soil because the former had higher concentrations of available $\mathrm{NH}_{4}{ }^{+}-\mathrm{N}$ and $\mathrm{NO}_{3}{ }^{-}-\mathrm{N}$ and lower leaching loss of $\mathrm{NH}_{4}{ }^{+}-\mathrm{N}$ and $\mathrm{NO}_{3}{ }^{-}-\mathrm{N}$. Therefore, the use of $\mathrm{LU}$ would benefit the farmers because it would have higher NUE than the GU. However, the results should be confirmed by glasshouse study.

Author Contributions: All authors contributed significantly to develop, procedure and writingreviewing and editing. A.M.M. conducted the experiment, investigation, formal analysis, visualization, writing - original draft of the manuscript. Editing and approval of final version of the manuscript by A.W.S., A.S.A.S. and A.M.A. All authors have read and agreed to the published version of the manuscript.

Funding: The first author was sponsored by the NATP Phase-II project of Bangladesh Agricultural Research Council (BARC) for his PhD study. This study was sponsored by a grant from BARC (Grant number-6282521-10201).

Institutional Review Board Statement: Not applicable.

Informed Consent Statement: Not applicable.

Data Availability Statement: Not any.

Acknowledgments: The authors are thanks to the Universiti Putra Malaysia (UPM) and Soil Resources Development Institute (SRDI), People's Republic of Bangladesh for their support in conducting this research.

Conflicts of Interest: The authors have no conflict of interest to publish this manuscript. 


\section{References}

1. Cropnuts Nitrogen-Nutrient Management I Mosaic Crop Nutrition. Available online: https:/ /www.cropnutrition.com/nutrientmanagement/nitrogen (accessed on 17 May 2020).

2. Erisman, J.W.; Sutton, M.A.; Galloway, J.; Klimont, Z.; Winiwarter, W. How a century of ammonia synthesis changed the world. Nat. Geosci. 2008, 1, 636-639. [CrossRef]

3. Leghari, S.J.; Wahocho, N.A.; Laghari, G.M.; HafeezLaghari, A.; MustafaBhabhan, G.; HussainTalpur, K.; Bhutto, T.A.; Wahocho, S.A.; Lashari, A.A. Role of Nitrogen for Plant Growth and Development: A review. Adv. Environ. Biol. 2016, 10, $209-218$.

4. Kira, O.; Shaviv, A.; Dubowski, Y. Science of the Total Environment Direct tracing of $\mathrm{NH}_{3}$ and $\mathrm{N}_{2} \mathrm{O}$ emissions associated with urea fertilization approaches, using static incubation cells. Sci. Total Environ. 2019, 661, 75-85. [CrossRef] [PubMed]

5. Sutton, M.A.; Oenema, O.; Erisman, J.W.; Leip, A.; van Grinsven, H.; Winiwarter, W. Too much of a good thing? Nature 2011, 472, 156-161. [CrossRef]

6. Heffer, P.; Prud'homme, M. Short-Term Fertilizer Outlook 2016-2017; International Fertilizer Industry Association: Paris, France, 2016.

7. Almaz, M.G.; Halim, R.A.; Martini, M.Y.; Samsuri, A.W. Integrated application of poultry manure and chemical fertiliser on soil chemical properties and nutrient uptake of maize and soybean. Malays. J. Soil Sci. 2017, 21, 13-28.

8. Rochette, P.; Angers, D.A.; Chantigny, M.H.; Macdonald, J.D.; Bertrand, N. Reducing ammonia volatilization in a no-till soil by incorporating urea and pig slurry in shallow bands. Nutr. Cycl. Agroecosyst. 2009, 71-80. [CrossRef]

9. Puga, A.P.; Grutzmacher, P.; Cerri, C.E.P.; Ribeirinho, V.S.; de Andrade, C.A. Biochar-based nitrogen fertilizers: Greenhouse gas emissions, use efficiency, and maize yield in tropical soils. Sci. Total Environ. 2020, 704, 135375. [CrossRef]

10. Lichiheb, N.; Myles, L.T.; Personne, E.; Heuer, M.; Buban, M.; Nelson, A.J.; Koloutsou-Vakakis, S.; Rood, M.J.; Joo, E.; Miller, J.; et al. Implementation of the effect of urease inhibitor on ammonia emissions following urea-based fertilizer application at a Zea mays field in central Illinois: A study with SURFATM-NH 3 model. Agric. For. Meteorol. 2019, 269-270, 78-87. [CrossRef]

11. Motasim, A.M.; Samsuri, A.W.; Shairah, A.S.A.; Adibah, A.M. Gaseous Nitrogen Losses from Tropical Soils with Liquid or Granular Urea Fertilizer Application. Sustainability 2021, 13, 3128. [CrossRef]

12. Wesley, T.L.; Lamond, R.E.; Martin, V.L.; Duncan, S.R. Effects of late-season nitrogen fertilizer on irrigated soybean yield and composition. J. Prod. Agric. 1998, 11, 331-336. [CrossRef]

13. Walsh, O.S.; Christiaens, R.J.; Pandey, A. Applying Liquid Nitrogen in spring wheat. Fluid J. 2014, 22-1, 4-8.

14. Walsh, O.S.; Christiaens, R.J. Relative Efficacy of Liquid Nitrogen Fertilizers in Dryland Spring Wheat. Int. J. Agron. 2016, 2016. [CrossRef]

15. McLaughlin, M.J.; McBeath, T.M.; Smernik, R.; Stacey, S.P.; Ajiboye, B.; Guppy, C. The chemical nature of P accumulation in agricultural soils-implications for fertiliser management and design: An Australian perspective. Plant Soil 2011, 349, 69-87. [CrossRef]

16. Singh, J.; Mahal, J.S.; Manes, G.S.; Singh, M. Development and evaluation of nitrogen (liquid Urea) applicator for straw mulched no-till wheat residue simultaneously. Agric. Eng. Intern. CIGR J. 2013, 15, 30-38.

17. Da Silva, M.J.; Magalhães, H.C.J.; Graziano, F.P.S. Liquid fertilizer application to ratoon cane using a soil punching method. Soil Tillage Res. 2017, 165, 279-285. [CrossRef]

18. Zhao, M.; Tian, Y.; Ma, Y.; Zhang, M.; Yao, Y.; Xiong, Z.; Yin, B.; Zhu, Z. Mitigating gaseous nitrogen emissions intensity from a Chinese rice cropping system through an improved management practice aimed to close the yield gap. Agric. Ecosyst. Environ. 2015, 203, 36-45. [CrossRef]

19. LECO. LECO Corporation, USA. Available online: https://www.leco.com/about-us/corporate/approved-methods (accessed on 30 November 2018).

20. Chapman, H.D. Cation-exchange capacity. Methods Soil Anal. Part 2 Chem. Microbiol. Prop. 1965, 9, 891-901.

21. Teh, C.B.S.; Talib, J. Soil and Plant Analyses Vol. I Soil Physics Analyses; Department of Land Management, Faculty of Agriculture, Universiti Putra Malaysia: Serdang, Malaysia, 2006; Volume 1, ISBN 983-3455-64-6.

22. Tan, K.H. Determination of soil water. In Soil Sampling, Preparation, and Analysis, 2nd ed.; CRC Press: Boca Raton, FL, USA, 2005; Volume 1, ISBN 9780849334993.

23. Min, L.W. Reconnaissance Soil Survey of Raub-Temerloh-Jerantut Region Northwest Pahang; Soil Science Division, Research Branch, Division of Agriculture, Ministry of Agriculture and Co-Operatives: Kuala Lumpur, Malaysia, 1967; Volume 2.

24. Keeney, D.R.; Nelson, D.W. Nitrogen-Inorganic Forms. Methods Soil Anal. Part 2. Chem. Microbiol. Prop. 1982, 5, $643-698$.

25. Douglas, L.A.; Bremner, J.M. Extraction and colorimetric determination of urea in soils. Soil Sci. Soc. Am. J. 1970, 34, 859-862. [CrossRef]

26. Zadeh, F.S. Sorption-Desorption, Degradation and Leaching of Napramide in Selected Malaysian Soils; University Putra Malaysia: Serdang, Malaysia, 2010.

27. SAS Institute Inc. SAS®9.4 Statements Reference; SAS Institute Inc.: Cary, NC, USA, 2013; p. 476.

28. Mariano, E.; de Sant, A.F.C.R.; Bortoletto-Santos, R.; Bendassolli, J.A.; Trivelin, P.C.O. Ammonia losses following surface application of enhanced-efficiency nitrogen fertilizers and urea. Atmos. Environ. 2019, 203, 242-251. [CrossRef]

29. Abera, G.; Wolde-Meskel, E.; Beyene, S.; Bakken, L.R. Nitrogen mineralization dynamics under different moisture regimes in tropical soils. Int. J. Soil Sci. 2012, 7, 132. [CrossRef]

30. Cardenas, L.M.; Scholefield, D.; Clark, I.M.; Hirsch, P.R. Potential mineralization and nitrification in volcanic grassland soils in Chile. Soil Sci. Plant Nutr. 2013. [CrossRef] 
31. Bundy, L.G. Managing Urea-Containing Fertilizers. In Proceedings of the Fertilizer Dealer Meeting, Madison, WI, USA, 27 November-6 December 2001; pp. 1-6.

32. Rochette, P.; Angers, D.A.; Chantigny, M.H.; Gasser, M.O.; MacDonald, J.D.; Pelster, D.E.; Bertrand, N. NH 3 volatilization, soil $\mathrm{NH} 4+$ concentration and soil $\mathrm{pH}$ following subsurface banding of urea at increasing rates. Can. J. Soil Sci. 2013, 93, 261-268. [CrossRef]

33. Rochette, P.; Angers, D.A.; Chantigny, M.H.; Macdonald, J.D.; Bissonnette, N.; Bertrand, N. Ammonia volatilization following surface application of urea to tilled and no-till soils: A laboratory comparison. Soil Tillage Res. J. 2009, 103, 310-315. [CrossRef]

34. Junejo, N.; Khanif, M.Y.; Hanfi, M.M.; Dharejo, K.A.; Wan, Z.W.Y. Reduced loss of NH3 by coating urea with biodegradable polymers, palm stearin and selected micronutrients. Afr. J. Biotechnol. 2011, 10, 10618-10625. [CrossRef]

35. Mukhopadhyay, S.; Masto, R.E.; Tripathi, R.C.; Srivastava, N.K. Application of Soil Quality Indicators for the Phytorestoration of Mine Spoil Dumps; Elsevier Inc.: Amsterdam, The Netherlands, 2019; ISBN 9780128139134.

36. Zuki, M.M.B.M. Nitrogen (N) Transformation of NBPT Treated Urea on Growth and Yield of Maize (Zea mays var. Thai Super Sweet). Master's Thesis, Universiti Putra Malaysia, Serdang, Malaysia, 2020.

37. Gioacchini, P.; Nastri, A.; Marzadori, C.; Giovannini, C.; Antisari, L.V.; Gessa, C. Influence of urease and nitrification inhibitors on N losses from soils fertilized with urea. Biol. Fertil. Soils 2002, 36, 129-135. [CrossRef]

38. Omar, L.; Ahmed, O.H.; Muhamad, N.; Majid, A. Improving Ammonium and Nitrate Release from Urea Using Clinoptilolite Zeolite and Compost Produced from Agricultural Wastes. Sci. World J. 2015, 2015, 12. [CrossRef] [PubMed]

39. Ma, Z.; Yue, Y.; Feng, M.; Li, Y.; Ma, X.; Zhao, X.; Wang, S. Mitigation of ammonia volatilization and nitrate leaching via loss control urea triggered H-bond forces. Sci. Rep. 2019, 9, 1-9. [CrossRef]

40. Tripolskaja, L.; Verbylienè, I. The effect of different forms of nitrogen fertilizers on nitrogen leaching. Zemdirbyste 2014, 101, 243-248. [CrossRef]

41. Pedersen, A.; Stoumann, L.; Thorup-kristensen, K. A model analysis on nitrate leaching under different soil and climate conditions and use of catch crops. In Proceedings of the N Management in Agrosystems in Relation to the Water Framework Directive, Maastricht, The Netherlands, 24-26 October 2005; p. 1.

42. Ulén, B.; Aronsson, H. Nitrogen and phosphorus leaching under the potential biennial oilseed plant Lepidium campestre L. in a field trial. Acta Agric. Scand. Sect. B Soil Plant Sci. 2018, 68, 555-561. [CrossRef] 